\title{
Relationship between Maternal Thyroid autoantibodies, Preterm Delivery and Neonatal Disorders: Potential Challenges
}

\author{
Ahmed RG* \\ Division of Anatomy and Embryology, Department of Zoology, Beni Suef University, Egypt
}

Submission: March 19, 2018; Published: March 26, 2018

*Corresponding author: Ahmed RG, Division of Anatomy and Embryology, Department of Zoology, Beni Suef University, Egypt,

Tel/Fax: 002-010-91471828; Email: ahmedragab08@gmail.com

\section{Commentary}

The regular changes in the maternal thyroid hormones (THs; 3,5,3'-triiodothyronine (T3) and thyroxin (T4)) economy during the gestation necessitate the establishment of normal delivery and fetal-neonatal development [1-72]. It is recognized that gestational immune modulation can decline the levels of thyroperoxidase antibody (TPOAb) with the progress of gestation and occasionally TPOAb became negligence during the later pregnancy [73]. On the other hand, an autoimmune disease (AID) is accompanying with circulating auto antibodies (self-reactivity of a different protein), mainly mediated by autoimmune $T$ lymphocytes, and caused several tissue damages and inflammation [74-76].In addition, these circulating auto antibodies are established for many years before the beginning of a disease. The presence of TPOAb during pregnancy can increase the risk of maternal thyroid dysfunctions, and cause a hypothyroidism [77-81] and premature delivery [82-85,80].

This autoimmunity is reinforced by the higher level of median thyroid-stimulating hormone (TSH) and the higher risk of gestational hypothyroidism [86-87]. As well, there is a relationship between the maternal TPOAb and thyroglobulin antibodies (TgAbs) and irregular obstetric consequence $[82,84,88]$ such as placental abruption, fetal growth retardation, miscarriage, and neonatal neuropsychological (motor, cognitive, and attention) disorders [89-92]. Also, thyroid autoantibodies can increase the risk of miscarriage [82], neonatal respiratory distress syndrome [93], and cardiovascular, metabolic, and renal disorders [94-97]. More interestingly, [98,92] reported that TPOAb positive during the gestation can cause polyhydramnios and postpartum thyroiditis (PPT). The presence of thyroid antibodies before the gestation can increase the prevalence of gestational complications [99-109]. Finally, thyroid auto antibodies may induce these disorders as the following [102$104,82,106,101]$. a) Alter the levels of TSH and the outline of endometrial T cells.

b) Decrease the secretion of interleukins (IL-4 and -10).

c) Increase the secretion of interferon $\gamma$.

d) Elevate the migration process of cytotoxic natural killer cells.

e) Disrupt the uterine hormonal and immune responses.

f) Perturb the levels of cytokine networks (inflammatory processes) during the placental-decidual (fetoplacental) development.

g) Maternofetal immune dysregulations.

Collectively, the present commentary suggested that the occurrence of thyroid auto antibodies (TPOAb and TgAbs) during the gestation may cause several pregnancy complications, thyroid disorders (hypothyroidism and PPT), teratogenic outcomes, preterm birth, and fetal and neonatal neuro developmental dysfunctions. These disorders may be mediated by the hormonal-immune dysregulations and may impact the development and childhood life. However, the possible effects of TPOAb and TgAbs on fetal-neonatal neurodevelopment warrant additional examination. Also, screening of maternal thyroid function before and at early pregnancy should be performed specifically in TPOAb- or TgAbs positive pregnant. Such monitoring may be improved the maternofetal, neonatal and child health consequences.

\section{References}

1. Ahmed RG (2011) Perinatal 2, 3, 7, 8-tetrachlorodibenzo-p-dioxin exposure alters developmental neuroendocrine system. Food Chem Toxicology 49(6): 1276-1284.

2. Ahmed RG, (2012) Maternal-newborn thyroid dysfunction. In the Developmental Neuroendocrinology: pp. 1-369. 
3. Ahmed RG (2012) Maternal-fetal thyroid interactions, Thyroid Hormone. In Tech Open Access Publisher: pp. 125-156

4. Ahmed RG (2013) Early weaning PCB 95 exposure alters the neonatal endocrine system: thyroid adipokine dysfunction. J Endocrinol 219(3): 205-215.

5. Ahmed RG (2014) Editorial: Do PCBs modify the thyroid-adipokine axis during development? Annals Thyroid Res 1(1): 11-12.

6. Ahmed RG (2015) Chapter 1: Hypothyroidism and brain development. In advances in hypothyroidism treatment: pp. 1-40.

7. Ahmed RG (2015) Hypothyroidism and brain developmental players. Thyroid Research J 8(2): 1-12.

8. Ahmed RG (2015) Editorials and Commentary: Maternofetal thyroid action and brain development. J. of Advances in Biology 7(1): 12071213.

9. Ahmed RG (2016) Gestational dexamethasone alters fetal neuroendocrine axis. Toxicology Letters 258: 46-54.

10. Ahmed RG (2016) Neonatal polychlorinated biphenyls-induced endocrine dysfunction. Ann Thyroid Res 2(1): 34-35.

11. Ahmed RG (2016) Maternal iodine deficiency and brain disorders. Endocrinol Metab Syndr 5: 223.

12. Ahmed RG (2016) Maternal bisphenol A alters fetal endocrine system: Thyroid adipokine dysfunction. Food Chem. Toxicology 95: 168-174.

13. Ahmed RG (2017) Developmental thyroid diseases and GABAergic dysfunction. EC Neurology 8.1: 02-04.

14. Ahmed RG (2017) Hyperthyroidism and developmental dysfunction. Arch Med 9: 4.

15. Ahmed RG (2017) Anti-thyroid drugs may be at higher risk for perinatal thyroid disease. EC Pharmacology and Toxicology 4(4): 140-142.

16. Ahmed RG (2017) Perinatal hypothyroidism and cytoskeleton dysfunction. Endocrinol Metab Syndr 6: 271.

17. Ahmed RG (2017) Developmental thyroid diseases and monoaminergic dysfunction. Advances in Applied Science Research 8(3): 01-10.

18. Ahmed RG (2017) Hypothyroidism and brain development. J Anim Res Nutr 2(2): 13 .

19. Ahmed RG (2017) Antiepileptic drugs and developmental neuroendocrine dysfunction: Every why has A Wherefore. Arch Med $9(6): 2$.

20. Ahmed RG (2017) Gestational prooxidant-antioxidant imbalance may be at higher risk for postpartum thyroid disease. Endocrinol Metab Syndr 6: 279.

21. Ahmed RG (2017) Synergistic actions of thyroid-adipokines axis during development. Endocrinol Metab Syndr 6: 280.

22. Ahmed RG (2017) Thyroid-insulin dysfunction during development International Journal of Research Studies in Zoology 3(4): 73-75.

23. Ahmed RG (2017) Developmental thyroid diseases and cholinergic imbalance. International Journal of Research Studies in Zoology 3(4): 70-72.

24. Ahmed RG (2017) Thyroid diseases and developmental adenosinergic imbalance. Int J Clin Endocrinol 1(2): 053-055.

25. Ahmed RG (2017) Maternal anticancer drugs and fetal neuroendocrine dysfunction in experimental animals. Endocrinol Metab Syndr 6(6): 281.

26. Ahmed RG (2017) Letter: Gestational dexamethasone may be at higher risk for thyroid disease developing peripartum. Open Journal of Biomedical and Life Sciences (Ojbili) 3(2): 01-06.
27. Ahmed RG (2017) Deiodinases and developmental hypothyroidism. EC Nutrition 11.5: 183-185.

28. Ahmed RG (2017) Maternofetal thyroid hormones and risk of diabetes. Int $J$ of Res Studies in Medical and Health Sciences 2(10): 18-21.

29. Ahmed RG (2017) Association between hypothyroidism and renal dysfunctions. International Journal of Research Studies in Medical and Health Sciences 2(11): 1-4.

30. Ahmed RG (2017) Maternal hypothyroidism and lung dysfunction. International Journal of Research Studies in Medical and Health Sciences 2(11): 8-11.

31.Ahmed RG (2017) Endocrine disruptors; possible mechanisms for inducing developmental disorders. International journal of basic science in medicine (IJBSM) 2(4): 157-160.

32. Ahmed RG (2017) Maternal thyroid hormones trajectories and neonatal behavioral disorders. ARC Journal of Diabetes and Endocrinology 3(2): 18-21.

33. Ahmed RG (2017) Maternal thyroid dysfunction and neonatal cardiac disorders. Insights Biol Med 1: 092-096.

34. Ahmed RG (2018) Maternal hypothyroidism and neonatal testicular dysfunction. International Journal of Research Studies in Medical and Health Sciences 3(1): 8-12.

35. Ahmed RG (2018) Maternal hypothyroidism and neonatal depression: Current perspective. International Journal of Research Studies in Zoology 4(1): 6-10.

36. Ahmed RG (2018) Non-genomic actions of thyroid hormones during development. App Clin Pharmacol Toxicol:

37. Ahmed RG (2018) Maternal thyroid function and placental hemodynamics. ARC Journal of Animal and Veterinary Sciences 4(1): 9-13

38. Ahmed RG (2018) Interactions between thyroid and growth factors during development. ARC Journal of Diabetes and Endocrinology 4(1): $1-4$

39. Ahmed RG (2018) Maternal thyroid hormones and neonatal appetite. ARC Journal of Nutrition and Growth 4(1): 18-22.

40. Ahmed RG (2018) Genomic actions of thyroid hormones during development. ARC Journal of Diabetes and Endocrinology 4(1): 5-8.

41. Ahmed RG (2018) Dysfunction of maternal thyroid hormones and psychiatric symptoms. American Research Journal of Endocrinology 2(1): 1-6.

42. Ahmed RG (2018) Is there a connection between maternal hypothyroidism and developing autism spectrum disorders? ARC Journal of Neuroscience 3(1): 5-8.

43. Ahmed RG (2018) Maternal thyroid dysfunctions and neonatal bone maldevelopment. American Research Journal of Endocrinology (in press) $\mathrm{xx}$-xxx.

44. Ahmed RG (2018) Maternal thyroid disorders and risk of neonatal seizure: Current perspective. ARC Journal of Neuroscience 3(1): 21-25.

45. Ahmed RG $(20180$ Gestational dioxin acts as developing neuroendocrine-disruptor. EC Pharmacology and Toxicology 6.3: 96100.

46. Ahmed RG (2018) Maternal thyroid dysfunction and risk of neonatal stroke. ARC Journal of Animal and Veterinary Sciences 4(1): 22-26.

47. Ahmed RG (2018) Maternal thyroid disorders and developing skin dysfunctions. ARC Journal of Dermatology 3(1): 13-17.

48. Ahmed RG (2018) Maternal hypothyroidism-milk ejections: What is the link? ARC Journal of Nutrition and Growth 4(1): 29-33 
49. Ahmed RG (2018) Does maternal antepartum hypothyroidism cause fetal and neonatal hyponatremia? ARC Journal of Diabetes and Endocrinology 4(1).

50. Ahmed RG (2018) Maternal hypothyroidism and rheumatoid arthritis. International Journal of Research Studies in Medical and Health Sciences Volume 3(2): 1-5.

51. Ahmed RG (2018) Developmental thyroid and skeletal muscle dysfunction. ARC Journal of Diabetes and Endocrinology 4(1).

52. Ahmed RG (2018) Hyperthyroidism and renal disorders. ARC Journal of Animal and Veterinary Sciences 4(2): 1-5.

53. Ahmed RG (2018) Maternal hypothyroidism and developing hyperhomocysteinemia. ARC Journal of Nutrition and Growth 4(2): 5-9.

54. Ahmed RG (2018) Maternal hyperthyroidism and neonatal testicular dysfunction. ARC Journal of Urology 3(1): 8-12.

55. Ahmed RG, (2018) Maternal hypothyroidism-developing dyslipidemia: What is the connection? ARC Journal of Pharmaceutical Sciences (AJPS) 4(1): 1-6.

56. Ahmed RG (2018) Maternal iodine deficiency and pregnancy complications: Still a health issue for the pregnant and fetuses. ARC Journal of Pharmaceutical Sciences 4(1): 7-11.

57. Ahmed OM, Ahmed RG (2012) Hypothyroidism. In A New Look At Hypothyroidism Dr D In Tech Open Access Publisher: 1-20.

58. Ahmed OM, Ahmed RG, El-Gareib AW, El-Bakry AM, Abd El-Tawab SM (2012) Effects of experimentally induced maternal hypothyroidism and hyperthyroidism on the development of rat offspring: II-The developmental pattern of neurons in relation to oxidative stress and antioxidant defense system. Int J Dev Neurosci 30(60): 517-537.

59. Ahmed RG, Davis PJ, Davis FB, De Vito P, Farias RN, et al. (2013) Nongenomic actions of thyroid hormones: from basic research to clinical applications. An update. Immunology Endocrine and Metabolic Agents in Medicinal Chemistry 13(1): 46-59.

60. Ahmed RG, Incerpi S, Ahmed F, Gaber A (2013) The developmental and physiological interactions between free radicals and antioxidant: Effect of environmental pollutants. J of Natural Sci Res 3(13): 74-110.

61. Ahmed RG, El-Gareib AW (2014) Lactating PTU exposure: I- Alters thyroid-neural axis in neonatal cerebellum. Eur J of Biol and Medical Sci Res 2(1): 1-16.

62. Ahmed RG, Abdel-Latif M, Ahmed F (2015) Protective effects of GM-CSF in experimental neonatal hypothyroidism. International Immunopharmacology 29(2): 538-543.

63. Ahmed RG, Abdel-Latif M, Mahdi E, El-Nesr K (2015) Immune stimulation improves endocrine and neural fetal outcomes in a model of maternofetal thyrotoxicosis. Int Immunopharmacol 29(2): 714-721.

64. Ahmed RG, El-Gareib AW, Shaker HM (2018) Gestational $3,3^{\prime}, 4,4^{\prime}, 5$-pentachlorobiphenyl (PCB 126) exposure disrupts fetoplacental unit: Fetal thyroid-cytokines dysfunction. Life Sciences 192: 213-220.

65. Ahmed RG, Walaa GH, Asmaa FS (2018) Suppressive effects of neonatal bisphenol A on the neuroendocrine system. Toxicology and Industrial Health Journal (in press).

66. Ahmed RG, Incerpi S (2013) Gestational doxorubicin alters fetal thyroid-brain axis. Int J Devl Neuroscience 31(2): 96-104.

67. Ahmed RG, El-Gareib AW, Incerpi S (2014) Lactating PTU exposure: II-Alters thyroid-axis and prooxidant-antioxidant balance in neonatal cerebellum. Int Res J of Natural Sciences 2(1): 1-20.

68. Incerpi S, Hsieh MT, Lin HY, Cheng GY, De Vito P, et al. (2014) Thyroid hormone inhibition in L6 myoblasts of IGF-I-mediated glucose uptake and proliferation: new roles for integrin $\alpha v \beta 3$. Am J Physiol Cell Physiol
307(2): 150-161

69. Candelotti E, De Vito P, Ahmed RG, Luly P, Davis PJ, et al. (2015) Thyroid hormones crosstalk with growth factors: Old facts and new hypotheses. Immune Endoc and Metab. Agents in Med Chem 15: 71-85.

70. De Vito P, Candelotti E, Ahmed RG, Luly P, Davis PJ, et al (2015) Role of thyroid hormones in insulin resistance and diabetes. Immune Endoc and Metab Agents in Med Chem 15: 86-93.

71. El-Ghareeb AA, El-Bakry AM, Ahmed RG, Gaber A (2016) Effects of zinc supplementation in neonatal hypothyroidism and cerebellar distortion induced by maternal carbimazole. Asian Journal of Applied Sciences 4(04): 1030-1040.

72. Ahmed RG, El-Gareib AW (2017) Maternal carbamazepine alters fetal neuroendocrine-cytokines axis. Toxicology 382: 59-66.

73. Ekinci EI, Chiu WL, Lu ZX (2015) A longitudinal study of thyroid autoantibodies in pregnancy: the importance of test timing. Clinical Endocrinology 82(4): 604-610.

74. Rose NR, MacKay IR (2006) The autoimmune diseases. Elsevier Academic Press, USA.

75. Cooper G, Bynum M, Somers E (2009) Recent insights in the epidemiology of autoimmune diseases: improved prevalence estimates and understanding of clustering of diseases. J Autoimmun 33(3-4): 197-207.

76. Gomes V, Mesquita A, Capela C (2015) Autoimmune diseases and pregnancy: analysis of a series of cases. BMC Res Notes 8: 216.

77. Stagnaro-Green A, Abalovich M, Alexander E, Azizi F, Mestman J, et al. (2011) American Thyroid Association Taskforce on thyroid disease during pregnancy and postpartum. Guidelines of the American Thyroid Association for the diagnosis and management of thyroid disease during pregnancy and postpartum. Thyroid 21(10): 1081-1125.

78. De Groot L, Abalovich M, Alexander EK, Amino N, Barbour L, et al (2012) Management of thyroid dysfunction during pregnancy and postpartum: an Endocrine Society clinical practice guideline. J Clin Endocrinol Metab 97(8): 2543-2565.

79. Lazarus J, Brown RS, Daumerie C, Hubalewska-Dydejczyk A, Negro $\mathrm{R}$, et al. (2014) European thyroid association guidelines for the management of subclinical hypothyroidism in pregnancy and in children. Eur Thyroid J 3(2): 76-94.

80. Chan S, Boelaert K (2015) Optimal management of hypothyroidism, hypothyroxinaemia and euthyroid TPO antibody positivity preconception and in pregnancy. Clin Endocrinol (Oxf) 82(3): 313326.

81. Korevaar TIM, Steegers EAP, Pop VJ, Broeren MA, Chaker L, et al. (2017) Thyroid autoimmunity impairs the thyroidal response to human chorionic gonadotropin: Two population-based prospective cohort studies. J Clin Endocrinol Metab 102(1): 69-77.

82. Thangaratinam S, Tan A, Knox E, Kilby MD, Franklyn J, et al. (2011) Association between thyroid autoantibodies and miscarriage and preterm birth: meta-analysis of evidence. BMJ 342: pp: 2616.

83. He X, Wang P, Wang Z, He X, Xu D, et al. (2012) Thyroid antibodies and risk of preterm delivery: a meta-analysis of prospective cohort studies. Eur J Endocrinol. 167(4): 455-464.

84. Korevaar TI, Schalekamp-Timmermans S, de Rijke YB, Visser WE, Visser W, et al. (2013) Hypothyroxinemia and TPO-antibody positivity are risk factors for premature delivery: the generation R study. J Clin Endocrinol Metab 98(11): 4382-4390.

85. Medici M, de Rijke YB, Peeters RP, Visser W, de Muinck Keizer-Schrama SM, et al. (2012) Maternal early pregnancy and newborn thyroid hormone parameters: the Generation R study. J Clin Endocrinol Metab 97(2): 646-652. 
86. Bliddal S, Boas M, Hilsted L, Friis-Hansen L, Tabor A, (2015) Thyroid function and autoimmunity in Danish pregnant women after an iodine fortification program and associations with obstetric outcomes. European Journal of Endocrinology 173(6): 709-718.

87. Li Y, Shan Z, Teng W (2010) Abnormalities of maternal thyroid function during pregnancy affect neuropsychological development of their children at 25-30 months. Clinical Endocrinology 72(6): 825-829.

88. Ghassabian A, Bongers-Schokking JJ, De Rijke YB (2012) Maternal thyroid autoimmunity during pregnancy and the risk of attention deficit/hyperactivity problems in children: the generation $\mathrm{R}$ study. Thyroid 22(2): 178-186.

89. Léger J, dos Santos S, Larroque B, Ecosse E (2015) Pregnancy outcomes and relationship to treatment adequacy in women treated early for congenital hypothyroidism: a longitudinal population-based study. The Journal of Clinical Endocrinology and Metabolism 100(3): 860869 .

90. Chen X, Jin B, Xia J, Tao X, Huang X (2016) Effects of thyroid peroxidase antibody on maternal and neonatal outcomes in pregnant women in an iodine-sufficient area in China. International Journal of Endocrinology pp. 1-8.

91. Negro R, Schwartz A, Gismondi R, Tinelli A, Mangieri T, et al. (2011) Thyroid antibody positivity in the first trimester of pregnancy is associated with negative pregnancy outcomes. The Journal of Clinical Endocrinology and Metabolism 96(6): 920-924.

92. Vikse BE, Irgens LM, Leivestad T, Hallan S, Iversen BM (2008) Low birth weight increases risk for end-stage renal disease. J AmSoc Nephrol 19(1): 151-157.

93. Willemsen RH, de Kort SW, van der Kaay DC, Hokken-Koelega AC (2008) Independent effects of prematurity on metabolic and cardiovascular risk factors in short small-for-gestational-age children. J Clin Endocrinol Metab 93(2): 452-458.

94. Nosarti C, Reichenberg A, Murray RM, Cnattingius S, Lambe MP, et al. (2012) Preterm birth and psychiatric disorders in young adult life. Arch Gen Psychiatry 69(6): 1-8.

95. Kahaly GJ, Diana T, Glang J, Kanitz M, Pitz S, König J, et al (2016) Thyroid stimulating antibodies are highly prevalent in Hashimoto's thyroiditis and associated orbitopathy. J Clin Endocrinol Metab 101(5): 19982004.

96. Muller AF, Drexhage HA, Berghout A (2001) Postpartum thyroiditis and autoimmune thyroiditis in women of childbearing age: recent insights and consequences for antenatal and postnatal care. Endocrine Reviews 22(5): 605-630.

97. Krassas GE, Poppe K, Glinoer D (2010) Thyroid function and human reproductive health. Endocrine Reviews 31(5): 702-755.
98. Banerjee S (2011). Thyroid disorders in pregnancy. Journal of the Association of Physicians of India : 32-34.

99. Nazarpour S, Tehrani FR, Simbar M, Tohidi M, Majd HA, et al. (2017) Effects of levothyroxine treatment on pregnancy outcomes in pregnant women with autoimmune thyroid disease. European Journal of Endocrinology 176(2): 253-265.

100. Nakamura H, Usa T, Motomura M, Ichikawa T, Nakao K, et al. (2008) Prevalence of interrelated autoantibodies in thyroid diseases and autoimmune disorders. Journal of Endocrinological Investigation 31(10): 861-865.

101. Weetman AP (2010) Immunity, thyroid function and pregnancy: molecular mechanisms. Nature Reviews Endocrinology 6(6): 311318.

102. Alexander EK (2011) Autoimmunity: thyroid autoantibodies and pregnancy risk. Nature Reviews Endocrinology 7: 501-502.

103. Kim NY, Cho HJ, Kim HY, Yang KM, Ahn HK, et al. (2011) Thyroid autoimmunity and its association with cellular and humoral immunity in women with reproductive failures. American Journal of Reproductive Immunology 65(1): 78-87.

104. Triggianese P, Perricone C, Conigliaro P, Chimenti MS, Perricone R, et al. (2016) Peripheral blood natural killer cells and mild thyroid abnormalities in women with reproductive failure. International Journal of Immunopathology and Pharmacology 29(1): 65-75.

105. Poppe K, Glinoer D, Tournaye H, Schiettecatte J, Devroey P, et al. (2004) Impact of ovarian hyperstimulation on thyroid function in women with and without thyroid autoimmunity. J Clin Endocrinol Metab 89(8): 3808-3812.

106. Nakamura H, Usa T, Motomura M, Ichikawa T, Nakao K, et al. (2008) Prevalence of interrelated autoantibodies in thyroid diseases and autoimmune disorders. Journal of Endocrinological Investigation 31(10): 861-865.

107. Ahmed OM, El-Gareib AW, El-bakry AM, Abd El-Tawab SM, Ahmed RG (2008) Thyroid hormones states and brain development interactions. Int J Dev Neurosci 26(2): 147-209.

108. Ahmed OM, Abd El-Tawab SM, Ahmed RG (2010) Effects of experimentally induced maternal hypothyroidism and hyperthyroidism on the development of rat offspring: I- The development of the thyroid hormones-neurotransmitters and adenosinergic system interactions. Int J Dev Neurosci 28(6): 437454.

109. El-bakry AM, El-Ghareeb AW, Ahmed RG (2010) Comparative study of the effects of experimentally-induced hypothyroidism and hyperthyroidism in some brain regions in albino rats. Int J Dev Neurosci 28(5): 371-389.

\section{Your next submission with Juniper Publishers will reach you the below assets}

- Quality Editorial service

- Swift Peer Review

- Reprints availability

- E-prints Service

- Manuscript Podcast for convenient understanding

- Global attainment for your research

- Manuscript accessibility in different formats

( Pdf, E-pub, Full Text, Audio)

- Unceasing customer service

Track the below URL for one-step submission https://juniperpublishers.com/online-submission.php 